\title{
Die historiese Jesus, die Jesus-beweging \\ en die vorming van die kerk
}

Andries van Aarde

Universiteit van Pretoria

\begin{abstract}
The historical Jesus, the Jesus movement and the birth of the church The article focuses on the birth of the church. The point at which the church began its existence is located within the boundaries of formative Judaism. The parting of the ways is explained as a movement from faction to sect, to the eventual formation of the church in its own right as distinct from the synagogue. The historical Jesus should therefore not be seen as the founder of the church. However, the article argues that the relation of the life and death of the historical Jesus to the resurrection belief of the post-paschal Jesus movement constitutes the cradle of the church. This continuum between Jesus and New Testament Christendom is referred to by means of the German phrase die Sache Jesu. Reconsideration of this trajectory results in the conviction that the vision and program of the historical Jesus cannot be neglected when one reflects on the nature of the church in the New Testament or on the vocation of the church through history to the present day. Two thought complexes form the kernel of die Sache Jesu: God's unbounded presence and the concept that everyone has unmediated and non-hierarchical access to the grace of God.
\end{abstract}

\section{INLEIDING}

Die historiese en kritiese bewussyn in Bybelondersoek is die vrug van die Kerkhervorming, hoewel hierdie bewussyn eers gedurende die Aufklärung 'n besondere momentum gekry het. Hoe dit ook al sy, wanneer die kerklike tradisie in verband met enige saak - selfs oor die wese van die kerk - onkrities aanvaar word asof tradisie en Skrif sonder meer dieselfde is, is die uitwerking van die Reformasie ontkragtig. Dat dogma wel in ooreenstemming met die Bybel kan wees, word nie ontken nie. Die historiese bewussyn skep egter by die eksegeet ' $n$ afstand tussen kerklike tradisies en die Bybel. Vanuit die perspektief van die Reformasie moet die toepassing van die Bybel in 
die lewe van die kerk krities begelei word, sodat die hermeneutiese dwaling van misplaaste konkreetheid (kyk Van Aarde 1985:568-570) vermy kan word. Maar nie net die kerklike tradisies moet krities bejeën word nie, ook die tradisies in die Bybel - het Martin Luther ons geleer. Sy Was Christum treibet-beginsel is hiervan 'n aanduiding (kyk Luther 1522, WADB 7:382, $27=$ [1963] 1990:63). Waar 'geregtigheid' in die godsdiens, dit wil sê die regte verhouding waarin mense tot God behoort te staan, nie gevind word in God se versoeningdaad in die Jesus-gebeure - in die. $\delta \iota \kappa \alpha \iota \sigma u ́ v \eta \theta \varepsilon o \hat{v}$ — nie, is godsdiens eiegeregtigheid en kry mense en húlle idees verlossingswaarde. Maar dit is tevergeefs, want die heil kom extra nos.

Luther het derhalwe by my die oortuiging gewek dat die verkondiging van die kerk in dieselfde asem as die dogmas van die kerk genoem moet word, omdat beide die inherente moontlikheid het om so met menslike idees geklee te word dat dit God se daad in die Jesus-gebeure kan versluier. Reeds Paulus (2 Kor 2:17-3:18; Rom 9:31-10:4) het daarop gewys dat daar onder die Israeliete mense was wat met hulle interpretasie van die Skrifte nie die wil van God nie, maar hulle eie wil verneem het, omdat hulle nie Jesus Christus in die Skrifte gevind het nie - 'n sluier het gehang oor hulle hart

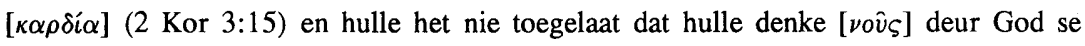
Gees vernuwe word nie (Rom 12:2). En nie net Israel was hiertoe geneig nie; ook die kerk sedert die begin. Hiervan is die Kerkhervorming 'n getuienis.

Verlossing is die gawe van God om van verganklikheid - dit wil sê ook en veral van die eiegeregtigheid waarmee die mens die heil soek in wat nietig is (Rom 10:2-4) - bevry te word. Ook die kerk is uitgelewer aan 'n bedeling wat verbygaan, en die oortuigings en verkondiging van die kerk kenmerk hierdie voorlopigheid (1 Kor 13:9). Friedrich Schleiermacher (kyk Christian 1979:109) het met skerp insig dwaalleer beskryf as iets met twee kante: eerstens, die ontkenning van die noodsaaklikheid om deur God van jouself bevry te word en tweedens, die weiering om te erken dat Jesus Christus die bewerker van God se bevryding is. Daarom wou Ernst Käsemann (1954:125153) hê dat die kerugmatiese Christus in die historiese Jesus geanker bly. Sy mentor, Rudolf Bultmann, het nie met hom hieroor verskil nie (kyk Schmithals, in Bultmann [1926] 1988:151-152). Inteendeel, Bultmann het die historiese Jesus as die vooronderstelling van die teologie geag. Jeremias (in Kümmel 1994:23-24) formuleer dit sterker wanneer hy nie net ons bemoeienis met die historiese Jesus sien as die wyse waarop ons 'vor Gott' gestel word nie, maar verder ook wat die Nuwe-Testamentiese wetenskap betref, sê: 'Darum ist die Bemühung um den historischen Jesus und seine Botschaft ... die zentrale Aufgabe der neutestamentlichen Forschung' (beklemtoning deur Jeremias). Wat Bultmann dus 'n 'vooronderstelling' noem, behoort geëkspliseer te word, sodat daar nie net volstaan word met die feit dat daar' $n$ historiese Jesus was wat gekruisig is 
nie, maar ook sodat die wat van die lewe en werk van Jesus wat op sy dood uitgeloop het, histories met meer sekerheid teruggevind word. Gerhard Ebeling ([1962] in Kümmel 1994:19) is reg: 'Begegnung mit dem Menschen Jesus heißt: Begegnung mit dem, was in ihm zur Sprache gekommen ist'. Indien ons nie hierdie vraag na die historiese Jesus vra nie, kan die kerugma en die kerklike belydenis ' $n$ ideologie word wat gemanipuleer word net soos mense wil, het Käsemann gesê. Kümmel beskryf James Robinson se waardering van die oplewing van historiese Jesus-navorsing wat deur Käsemann teweeggebring is, as ' $n$ gebeure wat nie los van Bultmann se invloed gesien moet word nie: 'Er versteht die mit Käsemann neu einsetzende Frage nach dem historische Jesus als ein Ereignis innerhalb der Bultmannschule' (Kümmel 1994:5).

In hierdie artikel wil ek ons oortuigings oor die wese van die kerk in verband bring met die geboorte van die kerk as voortspruitend uit die Jesus-gebeure. Die artikel fokus op die vorming van die kerk binne die grense van die eerste-eeuse Judaïsmes, en spesifiek teen die agtergrond van die Judaistiese hervorming na die vernietiging van die Jerusalemse tempel in $70 \mathrm{n} \mathrm{C} \mathrm{-} \mathrm{'n} \mathrm{gebeurtenis} \mathrm{wat} \mathrm{Jacob} \mathrm{Neusner} \mathrm{(1982)} \mathrm{formative} \mathrm{Ju-}$ daism noem. Die skeiding van die weë van die Christendom en die Jodedom word deur middel van die insigte van Bruce Malina [1994] voorgestel as 'n sosiologiese proses waarin die kerk vanaf faksie na sekte ontwikkel het om uiteindelik selfstandig kerk te wees. My diskoers word gestruktureer deur 'n aantal stellings met 'n kort besinning wat daarop volg. Hierdie artikel het nie die bedoeling om substansiërend op die velerlei aspekte van die geboorteproses van die kerk in te gaan nie. Alleen breë kontoere word aangedui. Die belangrikste aspek van die studie is om aan te toon hoe die Jesus-saak in kerkvorming oorgegaan het en dat die kerk as sosiologiese entiteit ontbinding in die gesig kan staar indien hierdie Jesus-saak nie sentraal in die roeping van die kerk bly staan nie. Om dié Jesus-saak te omlyn vereis 'n historiese ondersoek na die lewe van Jesus en die kontinuiteit daarvan in die lewe en verkondiging van die beweging wat sy volgelinge begin het en wat op die geboorte van die kerk uitgeloop het. Ek verwys na hierdie Jesus-beweging as die Nuwe-Testamentiese Christendom, want diversiteit in die Christendom is reeds baie vroeg histories aanduibaar. Saam met John Dominic Crossan (1994:3) - hy verwys daarna as die Algemene Christendom - beskryf ek hierdie Christendom as 'n daad van geloof in die historiese Jesus as die manifestasie van God.

Dit is my oortuiging dat Luther met sy Was Christum treibet-beginsel dieselfde beoog het as wat ek met die die term die Jesus-saak in die oog het. Ek grond hierdie oortuiging in my verstaan van Luther se hantering van apostolisiteit as die belangrikste kanonisiteitskriterium. In die slot van die artikel kom ek terug op die verband wat daar gelê kan word tussen die oorspronge van die kanon en die oorspronge van die kerk. Luther het as gevolg van die eerste resultate van die deurwerking van die kerkher- 
vormers se historiese bewussyn in kritiese Bybelwetenskap ${ }^{1}$ daarop gewys dat ons die koppeling van die ontstaan van kanonieke geskrifte aan 'apostels' nie letterlik (histories) moet opneem nie, maar saaklik (dogmaties; vgl Maurer 1960:62-63). Hiermee het hy bedoel dat God se spreke in die outentieke kerklike kerugma histories teruggevoer kan word na geloofwaardige tradente wat die Christus-gebeure voortdra (vg1 Kümmel 1970:76-77; Du Toit 1984:280). Willi Marxsen (1970:236) formuleer dit soos volg: 'Wenn wir nach der Kanonizität fragen, dann haben wir es zu tun mit dem Problem der Übertragbarkeit der Autorität'. Dit is 'n kwessie van 'n dialektiese verbinding in die Nuwe Testament tussen die 'normerende norm' (frühe Autorität) en die 'afgeleide norm' (abgeleitete Autorität) (Marxsen 1970:238). Die frühe Autorität word in Latyn getipeer as die principium canonicitatis (Du Toit 1984:99-108). Hierdie eerste gestalte van normatiwiteit is Jesus Christus wat die kerugma voorafgaan, maar dialekties nie daarvan losstaan nie.

In Luther se tyd - soos ook ten tyde van Paulus - was die onderskeid tussen die historische Jesus (wirkliche Christus) en die geschichtliche, biblische Christus (gepredigte Christus) nie getref nie. Dié terme kom voor in die titel van 'n boek, geskryf in 1896 deur Martin Kähler (1835-1912). Hierdie onderskeid tussen die historiese Jesus en die kerugmatiese Christus het die kontinuiteit of moontlike diskontinuïteit tussen die Jesus-gebeure en die kerklike kerugma in die kanon en in die kerklike tradisie in die oog. Dit is dus debatteerbaar om Luther se Was Christum treibet-beginsel as 'n 'kanon in die kanon' te tipeer (contra Du Toit 1984:281). Laasgenoemde uitdrukking kom gewoonlik neer op kanonreduksie en derhalwe op ' $n$ intoleransie teenoor die verskeidenheid in die Nuwe Testament. Luther het dié verskeidenheid getolereer, hoewel hy nie gehuiwer het om die genadedaad van God in die Jesus-gebeure as kritiese lig op die tradisie in die kanon en in die kerk te laat val nie. Die strewe om die Jesus-gebeure voorop te stel, sal ek eerder op grond van die insigte van Willi Marxsen bestempel as die 'kanon voor die kanon'. Die voorsetsel 'voor' het volgens Marxsen (1968:282284) hier, in hierdie uitdrukking, 'n saaklike én chronologiese voorrang (vgl Devenish 1992:xii, in Marxsen 1992).

Die feit dat ek tot sover die uitdrukkings Jesus-gebeure en Christus-gebeure uitruilbaar gebruik het, is doelbewus. Daarmee beklemtoon ek die saaklike kontinuïteit wat daar tussen die historiese Jesus en die kerklike verkondiging en belydenis behoort te bestaan.

\section{AANKNOPINGSPUNTE}

Enkele stellings van eksegete en teoloë dien in hierdie artikel as vertrekpunte vir die stellings wat bespreek gaan word. Hierdie stellings word vervolgens aangehaal en dit moet gesien word as aanknopingspunte van my eie diskoers: 
Jesus annonçait le royaume, et c'est l'eglise qui est venu (Jesus het die koninkryk aangekondig, en wat gekom het, is die kerk).

(Alfred Loisy, in Trilling 1978:68)

Die historische Wahrscheinlichkeit, das Jesus eine Kirche 'gedacht' 'gewollt' oder 'gegründet' - habe, ist aüssert gering ....

(Trilling 1978:68)

Osterglaube und Jesus-Bewegung sind zwei voneinander unterscheidbare, wenn auch aufeinander bezogene Phänomene.

(Schille 1994:104)

Universele Kirche, Kirche aus den Völkern ist nachösterlich geworden ... Das von Jesus verkündete Heil ist bezogen auf ein Volk, läszt sich nur realisieren in einem Volk ... Die Hinwendung zu den Völkern, prinzipiell in der Botschaft Jesu ermöglicht, war die notwendige theologische Folge.

(Gnilka 1993:202)

Alle Entwicklungen von Kirchenbegriff und Amtsverständnis vollziehen sich freilich im Rahmen der großen Entwicklungslinien, auf denen sich überhaupt die frühchristliche Theologiegeschichte bewegt, und haben seit jeher die Aufmerksamkeit der Historiker erregt. Hat Jesus die Kirche gegründet? Hat er sie überhaupt gewollt? Oder ist Ostern das Gründungsdatum der Kirche? Wie versteht sich die judenchristliche Urgemeinde selbst und welche Ordnung gibt sie sich? Der Übergang von Palästina in den Universalismus der 'damaszenischen' Bekehrungstheologie des Paulus einerseits, in das keineswegs einheitliche Judenchristentum der hellenistischen Synagogen andererseits führte zur Ausbildung von charakteristisch unterschiedlichen Kirchenbegriffen, die in den Briefen des Paulus, der sie in seiner eigenen 'Ekklesiologie' und bei der Ordnung und Leitung seiner Gemeinden miteinander verband, in ihrer jeweiligen Eigenart noch deutlich sichtbar werden. Der Ausschluß der christlichen Gemeinden aus der Synagoge und die innerkirchliche Auseinandersetzung um die rechte Lehre führten dann in der zweiten und dritten christlichen Generation zu jeweils charakteristischen Fortbildungen der 
kirchlichen Organisation und Ämterordnung, während die Lehrstreitigkeiten außerdem ebenso wie die Auswirkungen der Verfolgungszeit dazu nötigten, dem Problem der Kirchenzucht gezielte Aufmerksamkeit zuzuwenden.

(Schmithals 1994:155)

De ervaring van de eerste christelijke gemeenten, onafscheidelijk verbonden aan de directe omgang met Jezus ... zijn, historisch, de meest verantwoorde toegang tot Jezus van Nazaret ... Wat hij - alleen door wat hij was, deed en had gezegd, louter door zijn optreden als deze bepaalde mens - naliet, was een beweging, een levende gemeenschap van gelovigen, die sich ervan bewust werden het nieuwe Godsvolk te zijn, de eschatologische 'verzameling' van héél Israel, en tenslotte van heel het mensdom: een eschatologisch bevrijdende beweging om álle mensen te verzamelen: tot eenheid te brengen. Universele sjaloom.

(Schillebeeckx 1974:38)

De inclusiviteit van de Jezusbeweging wordt voortgezet in de vroegchristelijke beweging, zoals we horen uit beschrijvingen in andere delen van het Nieuwe Testament. Het was een van de meest in het oog lopende eigenschapppen van de beweging ... Ook de beroemde woorden van Paulus negeren de wereld van reinheid en culturele grenzen en drukken dezelfde inclusiviteit uit: 'In Christus is noch Jood noch Griek, slaaf noch vrije, man noch vrouw'. Paulus kondigt hier geen abstract ideaal aan; dit vers laat de nieuwe maatschappelijke realiteit van de beweging zelf zien.

(Borg 1995:76)

\section{DIE OPSTANDINGSGELOOF DIE BAKERMAT VAN DIE KERK}

Die kerk spruit voort uit die opstandingsgeloof, maar is gegrond in die Jesus-saak en die Jesus-saak is gewortel in die historiese Jesus wat sy boodskap binne die ruimte van Israel gebring het. Jesus het met ander woorde nie self die kerk bedink, gewil of gestig nie.

Die laaste $\sin$ in hierdie eerste stelling is die bekende woorde van Wolfgang Trilling (1978:68). Sedertdien is dit deur talle historici instemmend nagesê, waaronder Geza Vermes (1993:214-215) 'n onlangse voorbeeld is. Die oorspronge van die kerk word 
dus nie na 'n stigtingsgebeurtenis teruggevoer nie. Die totstandkoming van die kerk was 'n vormingsproses en dit kan as 'n beweging voorgestel word (kyk Schillebeeckx 1974:38; Schille 1994:104) wat teruggaan op die opstandingservarings van volgelinge van Jesus, soos veral Petrus, Maria Magdalena en Paulus (vgl Lüdemann 1994:68, 100, 170, 176-177 m b t Petrus en Paulus en die Jesus Seminar van die Westar Institute [1995] m b t Maria Magdalena, contra Lüdemann 1994:160).

'n Ander feit wat ook reeds lankal deur godsdienshistorici ingesien is, maar egter nie genoegsaam beklemtoon is nie en onlangs deur Joachim Gnilka (1993:202) in sy Jesus-boek weer onder ons aandag gebring is, is dat die 'kerk' begin het as ' $n$ beweging van Israeliete en nie as 'Christene' in die sin van Handelinge 11:26 nie. Hierdie beweging van Israeliete het iets van die grenslose sorg van God begin beleef in en deur hulle wedervaringe met of vanweë die tradisies oor die historiese Jesus,

* die vaderlose skrynwerker wat van die Galilese dorpie Nasaret kom;

* die seun van Maria wat in spanning met sy familie gestaan het;

* die 'Seun van God' wat op grond van 'n absolute vertroue in die teenwoordigheid van God as sy $A b b a$ voortbestaan het;

* die 'sondaar' wat aansluiting gevind het by die visie van Johannes die Doper dat sondaars vergifnis van God kan ontvang buite die strukture van die tempel om;

* die geesvervulde wysheidsleraar en geneser wat sy eie visie en belewenis van 'alternatiewe wysheid' deur middel van veral kernagtige simboliese spreuke, metaforiese vertellings, genesings en eksorsismes begin bekend maak het, en in sy eie lewe waar gemaak het dat God se 'onbemiddelde' en 'paradoksale' teenwoordigheid hiér en nóú (en nie alleen in die apokaliptiese sin dáár en later nie) manifesteer as 'n ontferming vir almal wat in die oë van selfgeregverdigdes niks is, niks het en niks jeens God en mens kan vergeld nie;

** en sodoende die koninkryk van God metafories herdefinieer het in terme van 'n nie-hiërargiese, denkbeeldige huishouding waarin al die lede van dié familie op 'n gelyke wyse direkte toegang tot die Vader het en die Vader vir diesulkes wat weet hoe arm hulle voor God is, omgee, en waarin hulle as denkbeeldige broers en susters van mekaar in gehoorsaamheid aan die wil van die Vader vir mekaar sorg dra;

** en vanweë sy konsistente en onverskrokke onkonvensionele houding en optrede met betrekking tot veral die tempelideologie met die Fariseërs in konflik gekom het, deur Saddusese priesterhooofde en familiehoofde as 'n bedreiging ervaar is, en deur die Romeinse prokurator, Pontius Pilatus, brutaal laat kruisig is asof hy 'n krimineel was (kyk Van Aarde [1995]:6). 
Die Jesus-saak kan in die lig van die kernsake in bogenoemde historiese konstruksie van die historiese Jesus opgesom word met die woorde swakheid, skande en dwaasheid, maar wat paradoksaal God se krag - dinamiek - was waarmee Hy die mag van die sonde gebreek het, die mens met Hom versoen het en in die regte verhouding met Hom gestel het. Hierdie bevryding word dus beleef ten spyte van (en eintlik veral vanweë) die skandelike dood en geboorte van Jesus. Om saam met Jesus te sterf, is vir byvoorbeeld Paulus om saam met Hom te lewe - nou nie meer aan die sondemag onderdanig nie, want $\mathrm{Hy}$ is tot sonde gemaak sodat ons op grond van hierdie gebeure in die regte verhouding met God gestel kan word (2 Kor 5:21; Gal 4:4; Rom 8:3 - vgl Schmithals 1994:91-92; Van Aarde [1995]:8-9, 14-15).

\section{3. 'N BEWEGING VIR EN VAN ANDER}

Dié Jesus-saak het spoedig ook 'n beweging geword vir en van 'ander' - Israeliete in die diaspora en Hellenistiese Godvresendes wat hulle met die godsdiens van die 'kinders van Abraham' geassosieer het. In hierdie Jesus-beweging het pioniers soos Paulus 'n groot rol gespeel.

Die oorspronge van die kerk is geleë in die opstandingservaring en die pneumatiese lewe van gelowiges in die eenheid met die opgestane Here - 'n eenheid wat deur Paulus met die formules $\dot{\varepsilon} \nu$ X $\rho \iota \tau \tau \hat{\varphi}, \dot{\varepsilon} \nu \kappa v \rho i \varphi$ en $\dot{\varepsilon} \nu \pi \nu \varepsilon \dot{\varepsilon} \mu \alpha \tau \iota$ uitgedruk is. Die kerk is dus 'n beweging van mense wat in Christus (X van die geloof vir onderskeidelik Israeliete en nie-Israeliete (vgl Bousset [1913] 1926:76-77; Van Aarde 1987:337), glo - soos Jesus, die Jesus van die geskiedenis,

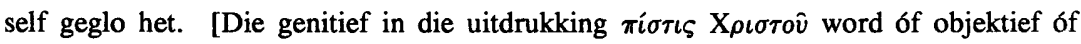
subjektief verstaan, afhangende van die konteks.] Jesus se interpretasie van die koninkryk van God, sy wysheid, sy herdefiniëring van die konsep 'kinders van Abraham' - 'kinders van God'- konstitueer die wesenlike van Christelike selfverstaan (vgl Cook 1993:62). Die wesenlike van die godsdiens is om te doen wat by God pas (Rom 12:1-2).

Indien verwerping en dood as 'n mislukking, dwaasheid of aanstoot gesien sou word, het Jesus se visie 'gefaal'. Maar hierdie paradoksale en aanstootlike persepsie dat krag in swakheid, wysheid in dwaasheid, eer in skande, lewe in sterwe moontlik is, behoort volgens die evangelie van Jesus Christus deel te wees van Christelike selfverstaan. Omdat God skande in eer omkeer, is die opstandingsgeloof die teken van 'n nuwe geboorte, 'n nuwe begin, 'n nuwe skepping (2 Kor 5:17; Gal 6:15): die geboorte van die 'ware Israel', die 'Israel van God' (Gal 6:16). Om die kerk se begronding in 
dié Jesus-saak (wat vir die wêreld dwaasheid is, maar vir oë van geloof wysheid) te ontken, is om die kerk se historiese bakermat te ontken en die wese van die kerk in 'n ekklesiologiese ideologie te vervlugtig. Daarom behoort die kern van die Pauliniese evangelie met betrekking tot die gekruisigde Christus (1 Kor 1:17-31) verstaan te word as die gekondenseerde geskiedenis van die historiese Jesus (vgl Crossan 1994:8-11). Tereg formuleer Crossan (1994:10) hierdie belangrike historiese kontinuum soos volg: 'Die historiese Jesus, veral wat sy verskriklike en vernederende dood [en sy nederige geboorte] betref, is vir Paulus deel van [die vooronderstelling tot] die Christelike geloof - dit is juis met betrekking tot die historiese Jesus wat só doodgemaak [en nederig gebore] is, dat Paulus met geloof geantwoord het' (my vertaling én byvoeging) ${ }^{2}$.

\section{JESUS - STIGTER VAN DIE KERK?}

Enkele, hoewel beperkte en histories onsekere, getuienisse in die Nuwe Testament voer die ontstaan van die kerk na Jesus self terug.

Drie verwysings in hierdie verband verdien vermelding. Die een is die Jesus-woord gerig tot Petrus in Matteus 16:17-19. Die ander is vooronderstel in die berig oor die instelling van die Nagmaal. Beide moet egter sonder twyfel laat dateer word en is boonop nie histories bevestigbaar nie (Conzelmann 1988:341). Die mees uitstaande Nuwe-Testamentiese bron wat iets sê oor die ontstaan van die kerk, is die Pauliniese credo in 1 Korintiërs 15:3-7 (Conzelmann 1973:94). Hiervolgens is Petrus (1 Kor 15:5a; kyk ook Luk 24:34) die eerste waarnemer van 'n verskyning van die Opgestane en derhalwe, histories gesien, die 'stigter' van die kerk - 'n geloofsbeskouing wat veronderstel dat dié stigting teruggevoer kan word na 'n daad van die opgestane Here. 'n Tweede aspek van hierdie credo is dat die Opgestane aan die Twaalf verskyn het (1 Kor 15:5b) en ook aan 'al die apostels' (1 Kor 15:7b). Na aanleiding hiervan kan geargumenteer word dat Jesus self 'die twaalftal' 'gelegitimeer' het en op dié wyse indirek aanleiding tot die ontstaan van die idee van die kerk (uitgedruk in 'die Twaalf' as verteenwoordigers van God se uitverkore volk) gegee het (Conzelmann 1988:341342). Wat egter in gedagte gehou moet word, is dat die benamings 'die Twaalf' en 'die apostels' nie uitruilbaar is nie en dat daar nie historiese getuienis bestaan dat Jesus verantwoordelik was vir die samestelling van sowel 'die Twaalf' as 'die apostels' nie (kyk Conzelmann 1988:303; contra Sanders 1985:11). Die belangstelling in die rol van die twaalftal dissipels en apostels as sodanig het eers in die loop van die geskiedenis van die vroeë kerk na aanleiding van die tradisies oor die opstandingsverskynings toegeneem, maar ontbreek in die vroegste Jesus-tradisies (bv wonders, chreias, 
apoftegmas en strydgesprekke). Hoewel dit as 'n klaarblyklike historiese waarskynlikheid geag kan word dat daar ten tyde van Jesus se dood reeds 'n soort groep volgelinge/ aanhangers van Jesus bestaan het (Conzelmann 1988:303), bly dit tog debatteerbaar of Jesus self 'n kleingroep van twaalf dissipels geroep en rondom Hom georganiseer het met die doel dat só 'n groep formeel sou uitloop op die.vorming van aanvanklik 'n faksie en later 'n sekte in terme van die formele strukture van tempel en sinagoge. Dit is meer waarskynlik dat die idee van die twaalftal (na aanleiding van die metaforiese konnotasie dat die twaalftal die eskatologiese 'ware' Israel verteenwoordig) tot stand gekom het as gevolg van die tradisies oor die verskynings van die Opgestane (kyk Conzelmann 1988:303).

\section{DIE JESUS-BEWEGING EN DIE VORMING VAN DIE KERK}

Dit is hoofsaaklik die inklusiewe perspektiewe wat daar by die historiese Jesus en in die Jesus-beweging aanwesig was, wat in die kerk tot volle uitdrukking gekom het. Daarom kan die Jesus-beweging en die vorming van die kerk nie in absolute diskontinuïteit met mekaar gesien word nie. Die Jesus van die geskiedenis en die Jesus-beweging is sonder die Paaskerugma denkbaar, maar nie kerkvorming nie. Tog gaan die een in die ander oor en is die Jesus-beweging en die ontstaan van die kerk, sosiohistories gesien, nie absoluut van mekaar te skei nie.

Histories gesien, is die ontstaan van die kerk (entstehende Kirche) nie identies aan die Jesus-beweging nie (Schille 1994:106). Maar ook die oortuigings van die Jesusbeweging is nie in alle opsigte identies aan die Jesus-saak nie. Onderskeidelik verteenwoordig die oorgang van die Jesus-beweging na die kerk fases van 'n sosiologiese proses. Diversiteit is reeds vroeg histories aanduibaar. Sekere strominge (byvoorbeeld die nie-kerugmatiese Jesus-volgelinge in Noord- en Transjordanië wat in sekere latere bronne bekendstaan as die Nasareërsekte en wat nou verwant was aan die Ebioniete) het hulle op die historiese Jesus beroep, maar eintlik in diskontinuiteit met die Jesus van die geskiedenis 'n eksklusiwistiese en nasionaal-partikuliere ideologie gehuldig. Of hierdie Jesus-volgelinge in dieselfde asem as of naas die Jerusalem-gemeente genoem moet word (kyk Strijdom 1995:112-113), maak eintlik nie saak nie. Hulle moet onderskei word van dié Jesus-beweging wat in die Lukaanse sendingteologie as 'Christene' (Hand 11:26) bestempel is. Wilhelm Bousset ([1913] 1926:75; vgl Schmithals 1994: 88, 90) het in hierdie verband tereg gesê: 'Zwischen Paulus und der palästinischen Urgemeinde stehen die hellenistischen Gemeinden in Antiochien, Damaskus, Tarsus'. Paulus van Tarsus is tot hierdie geloofsgemeenskap in Damaskus en Antiogië - 'n 
Jesus-beweging met 'n universele gerigtheid - bekeer. Dit was 'n bekering wat deur Paulus self beskryf is as sy ervaring dat die Gekruisigde leef, dat God sy Seun aan hom bekend gemaak het (Gal 2:12,16), dat hy saam met die Gekruisigde gekruisig is, sodat hy saam met die Gekruisigde leef (Gal 2:20; Fil 3:10-11). Die oorspronge van die kerk is in die kerugma van hierdie 'nuwe lewe' gegrond.

Die Jesus-beweging is sowel ' $n$ voor-Pase as 'n na-Pase gebeure, terwyl kerkvorming egter alleen ' $n$ na-Pase gebeure is. Die Jesus van die geskiedenis en sekere groepe in die Jesus-beweging (bv die Q-gemeenskap en die geadresseerdes van die Tomasevangelie) is sonder die paaskerugma denkbaar, maar nie kerkvorming nie. Die Jesusbeweging en die opkoms van die kerk is egter nie absoluut van mekaar te skei nie (Schille 1994:104). Dié kontinuiteit is, wat die proses van groepvorming betref, soos skakels van 'n ketting. Die eerste skakel verteenwoordig die fase waartydens 'n isolerende groep binne die grense van 'n ouerliggaam (parent body - vgl White 1988: 7-9; Stanton 1992:89-91) tot stand kom. Die 'ouerliggaam' is in hierdie geval die 'normatiewe Jodedom' (bestaande uit diverse groepe soos Sadduseërs, Fariseërs en Esseners) wat hulleself genealogies met behulp van die metafoor 'familie' gedefinieer het (Neusner 1987:331-361) en wel in biologiese sin as die 'kinders van Abraham' (Van Aarde 1993:515-545). Die aanvang van die eerste fase kan histories gesitueer word in die tyd toe Jesus nog aanklank by Johannes die Doper gevind het en sy eie dissipels begin 'werf' het.

\section{VAN FAKSIE TOT SEKTE TOT KERK}

Die eerste 'kerk' het ontstaan as 'n faksie binne die Jodedom. Verskille en spanninge oor bepaalde sake (veral die opstandingsgeloof, die geloof in die goddelike geboorte van Jesus en die nie-biologiese verstaan van die begrip 'kinders van Abraham') het daartoe gelei dat die 'kerk' vanaf faksie tot sekte ontwikkel, en uiteindelik los van en teenoor die sinagoge

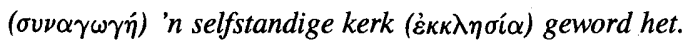

Die 'nie-biologiese' verstaan van die begrip 'kinders van Abraham' vind Schmithals (1994:156) besonder duidelik in Romeine 9:8 uitgedruk. Hiervolgens vorm die 'kinders van God' 'n denkbeeldige familie ${ }^{3}$. Soos ons reeds gesien het, is hierdie konsep by die historiese Jesus terug te vind. Die historiese Jesus wat in spanning met sy eie familie gestaan het (kyk Van Aarde [1995]), het die voorstelling gekoester van 'n denkbeeldige familiale struktuur waarin God die vaderrol vervul en die familielede se onderlinge verhouding as broers en susters nie noodwendig deur biologiese en derhalwe nasionale verwantskap bepaal was nie. Hierdie Godsbegrip het die basis gevorm van 
die sosiale konstituering van die Jesus-beweging (vgl Borg 1995:75-76). Dit is ook die basis van die fundamentele verskil tussen Israel en die kerk. Ook Israel het die metafoor 'familie' gebruik om te wys op die bande wat Israeliete onsigbaar aanmekaar bind. Hierin het die motivering gelê vir die ekskommunikasie van Christene. Christene het hulleself beskou as die 'geestelike Israel', terwyl die sinagoge daarop geroem het dat hulle 'Israel na die vlees' is (Neusner 1987) en dat 'genealogie' die binding hieraan aandui. Die genealogiese register van Jesus en die geboorte- en kindheidsvertelling in die Matteusevangelie reflekteer in hierdie verband die breuk tussen die kerk en die sinagoge op ' $n$ besondere wyse. Jesus se 'seunskap van Abraham' is nie op grond van biologiese verwantskap nie. Die kindheidsvertelling in die Matteusevangelie beklemtoon Jesus se 'legitimasie' deur God as 'Seun van God' (kyk Van Aarde 1994b:261-276). Die metafoor 'die kerk as die huishouding van God' (kyk Van Aarde 1990) is in hierdie Jesus-gebeure gebore. Dit verklaar ook, sover as wat daar van die 'uniekheid' van die vroegste Christendom in terme van die eerste-eeuse Jodedom gepraat kan word, die fundamentele onderskeid tussen die sinagoge en die kerk. Hierdie breuk tussen die sinagoge en die kerk (vgl Schmithals 1994:86, 111, 118, 169-176), dit wil sê die ontstaan en opkoms van die kerk, kan bestudeer word as 'n beweging vanaf faksie na sekte.

Kleingroepe word gevorm omdat 'n persoon bewus geword het van die noodsaaklikheid van verandering en hierdie bewussyn met ander begin deel het wat self onderling die verwagting gekoester het dat verandering in 'n bepaalde kulturele konteks wat ryp was vir nuwe groepvorming, suksesvol teweeggebring sal kan word (Malina 1994:6).

\subsection{Voorwaardes vir die vorming van 'n 'kleingroep' soos 'n faksie}

Die ondersoek van sosioloë na die faktore wat aanleiding gee tot die totstandkoming van 'faksies' in die samelewing is vir ons studie ter sake. Vier voorwaardes vir kleingroepvorming word onderskei (kyk Malina 1994):

* omstandighede vir verandering is gunstig;

* 'n visie op 'n nuwe situasie kom tot stand;

* dié visie gaan gepaard met 'n verwagting dat verandering suksesvol teweeggebring kan word;

* die sosiale sisteem (samelewing) waarbinne die verandering teweeggebring word, bevat inherent die moontlikheid dat probleem-oplossende groepe geakkommodeer word of gefasiliteer kan word. 


\subsubsection{Gunstige omstandighede}

Die manipulerende, eksploiterende en eksklusiwistiese tempelideologie van die 'normatiewe Judaïsme' het ten tyde van die historiese Jesus en die ontstaan van die Jesusbeweging ten hemele geskreeu (vgl Van Aarde 1993:519-521).

\subsubsection{Nuwe visie}

Die historiese Jesus bied 'n alternatiewe lewensorde (wysheid - vgl Borg 1995), herdefinieer die konsep mag ( = die idee van 'koninkryk' as die toppunt van mag in die sin van imperiale heerskappy) as ontfermende omgee en word self deur sy (dikwels metaforiese) woorde en dade die lewende simbool van hierdie visie. Dit fokus op sowel sy Godsvoorstelling as die samelewing, en wel in terme van 'n vader-seun verhouding.

\subsubsection{Verwagting op sukses}

Die entoesiasme dat bogenoemde visie besondere moontlikhede tot bekering en nuwe lewe bied, is histories in literatuur aanduibaar as iets wat in sowel voor-Pase as na-Pase Jesus-bewegings gegeld het. In die Paulus-beweging kom só 'n 'alternatiewe bewussyn' veral tot uitdrukking in die opstandingsgeloof.

\subsubsection{Ruimte vir verandering}

Die voor-70 n C akkommoderende gees binne die raamwerk van die verskeidenheid van Judaïsmes (Saddusese, Farisese en Esseense) het die vorming van die Jesus-faksie moontlik gemaak. Die na-70 n C onverdraagsaamkeid na aanleiding van die Farisese hervorming (kyk Neusner 1973) het die Jesus-faksie tot sekte laat ontwikkel en uiteindelik tot kerk los van en teenoor die 'formatiewe Judaïsme'. Laasgenoemde het in die 'rabbynse Judaïsme' oorgegaan.

\subsection{Fases in groepvorming}

Die volgende fases in groepvorming (kyk Malina 1994) kan, sosiologies gesien (kyk Tuckman 1965:384-399), onderskei word : vorming. (forming), 'storming' (storming), normering (norming), aksie (performing) en ontbinding (adjourning).

\subsubsection{Vorming}

Die historiese Jesus deel sy alternatiewe visie met soortgelyke 'ontnugterde' mense wat ly as gevolg van neerdrukkende omstandighede en vervreemding van God se teenwoordigheid. Hierdie fase is dié van die voor-pase Jesusbeweging. 


\subsection{2 'Storming'}

Jesus se 'bevrydende lewe' loop uit op die traumatiese kruisgebeure teen die agtergrond van die brutaliteit van die Romeinse imperiale mag, met die toedoen van Joodse 'koninklikes'. Die verwarring van ontnugterde dissipels loop uit op 'n diverse na-Pase Jesus-beweging en die herstel, waarvan ons veral in die Nuwe Testament lees, word deur hulle in die opstandingsgeloof gevind '(kyk Lüdemann 1994:176). Die diversiteit is die gevolg van waarskynlik 'n kompleks faktore:

* Die soeke na eie-identiteit in die lig van die wegbeweeg van 'normatiewe Judaïsme':

- moet die visie van Jesus gesien word as die 'nou poort' in onderskeid met die 'normatiewe Judaïsme as die 'breë poort' (die verlore Q-dokument - kyk Horsley 1989; Kloppenborg 1993:20-21)?

* Die interpretasie van Jesus se dood:

- hoe word die aanstoot van die kruisiging (die outeur van die Markusevangelie), die intense berou oor verloëning (Petrus), die vervolging van verkondigers van die Jesus-saak, selfs ná Jesus se dood (Paulus), en die intense persoonlike verlange en herinnering (Maria Magdalena) oorkom?

* Die grensoorskryding vanaf Israel na die heidene:

- is dit ' $n$ logiese noodwendigheid van Jesus se visie, sy inklusiwiteit en sy stoot teen die grense van die 'normatiewe' Joodse reinheidsmaatreëls waardeur die partikularistiese tempelideologie, die kalender en die etnies-besnede Abrahamskinders-idee instand gehou is (vgl Dunn 1991)?

* Die geloof/vertroue in/soos Jesus:

- eis dit 'n $\delta \iota \kappa \alpha \iota \sigma o ́ v \eta$ deur middel van die wet of nie (Paulus versus Petrus en Jakobus)?

\subsubsection{Normering}

Tydens hierdie fase ontstaan daar 'n mate van samehorigheid as gevolg van bepaalde kompromieë. Dit was die periode van kerkvorming en daar kan ook daarna verwys word as die 'vroeg-katolisisme'. In hierdie tyd mond die anti-hiërargiese en simboliese aard van die Jesus-saak uit in denkbeeldige huishoudingstrukture (Lukas-Handelinge, 1 Timoteus, Apostoliese Vaders). Die inklusiewe visie van die historiese Jesus en mense soos Paulus van Tarsus word georden in strukture wat ontdaan is van etniese begrensd- 
heid, hoewel die biologiese en hiërargiese familie die metafoor van dié pneumatiese en egalitêre 'familie' is. Dit is hierdie Jesus-beweging wat in die Antiogeense sendingsteologie in Handelinge 'Christene' genoem en waartoe Paulus bekeer is.

\subsubsection{Aksie}

Die fase van 'normering' gaan hand aan hand met die uitvoering van dié samebindende visie: die aanvanklike 'sending' oor grense (die Paulus-briewe en die Paulus-tradisies in Lukas-Handelinge) gaan oor in die sending na die gemarginaliseerdes, soos weduwees (ook diegene onder die Griekssprekendes), wese, straatkinders en duiwelbesetenes (bv die outeurs van Lukas-Handelinge en die Matteusevangelie, Klemens van Aleksandrië, die outeur van die brief aan Diognetus en die outeur van 1 Timoteus).

\subsubsection{Ontbinding}

Die tot niet gaan van die 'kerk' was reeds in die (implizite - Trilling 1978) vooraf fase, die voor-Pase Jesus-beweging, 'n sterk moontlikheid. Hoewel hierdie sosiaalwetenskaplike teorie hoofsaaklik betrekking het op die vorming en ontbinding van 'kleingroepe', kan die aspek met betrekking tot ontbinding van groepe ook toegepas word op op die na-Pase kerk as 'institusionele' organisasie. Menslik gesproke was ontbinding tydens die na-Pase periode en is dit vandag nog steeds ' $n$ moontlikheid wat nie buite rekening gelaat moet word nie. Fasette hiervan kan soos volg voorgestel word:

* Die voor-Pase Jesus-beweging het sigself vroeg reeds vasgeloop teen die 'skandaal' van Jesus se 'geboorte uit 'n nederige vrou' en sy kruisiging asof $\mathrm{Hy}$ 'n krimineel was, en het in die na-Pase periode van hierdie doodloopstraat 'n deurloopstraat gemaak deur die woorde en dade van Jesus, as 'God-met-ons', 'Seun van God', 'Beeld van God' ensovoorts, te laat voortleef. So byvoorbeeld het die Pauliniese Christendom die aanstoot van die kruis oorkom deur middel van die opstandingsgeloof wat in die werk van die Gees van God gegrond is, en in die Matteus- en Lukasevangelie is die geboorte van Jesus insgelyks as die werk van die Gees van God verstaan.

* Die gnostiese Christene het hulle vasgeloop teen die aposunagogos-beweging en die kerklike konsilies en het mettergaan nie oorleef nie. Die oopmaak van die Nag Hammadi-biblioteek in 1947 kan veroorsaak dat hulle geskrifte nuwe lewe in soortgelyke hedendaagse denkendes kan skep.

* Die Ebionitiese Nasareners het hulle teen die geloof in die opgestane Here, die vroeg-katolisisme en die latere ekumene vasgeloop en het alleen dáár bly voortbestaan waar die vroeë Antiogeense universele konnotasie van die woord 'Christene' nie as singewend geag is nie. 'n Soortgelyke proses duur tot vandag toe 
voort en die herlewing van die historiese Jesus-vraag sal diesulkes se 'eiegeregtigheid' met die Jesus van die geskiedenis konfronteer - natuurlik, indien hulle hulle vir die Jesus-saak sal oopstel.

* Aspekte van die Konstantyns-katolieke kerk het hulle teen die Renaissance, die humanisme en die sestiende-eeuse Reformasie vasgeloop. Die Rooms-Katolieke Kerk word tot vandag toe deur die Reformasie aan die historiese bewussyn herinner en waar dit ter harte geneem word, het dit vir sekere hedendaagse lidmate van dié kerk 'n terapeutiese uitwerking. Ook die Reformatoriese kerk het nog maar altyd 'n stryd om teen die hiërargiese sisteem in eie boesem te stry.

* Die moderne Christendom het teen institusionalisering en sekularisasie vasgeloop. Maar ook dié aanstoot kan oorkom word, indien ons die bewussyn vandag met mekaar kan deel dat die Jesus-saak inherent die dinamiek het om in 'n plurale en multi-kulturele postmoderne wêreld sin te gee aan 'ontnugterde' mense te midde van neerdrukkende omstandighede. Daar is egter voorwaardes: institutionalisering se remmende en doodsbestemde uitwerking sal teëgewerk moet word en sekularisasie sal gesien moet word as geleentheid vir die kerk om 'kerk vir die wêreld' te wees. Só gesien, kan ons na aanleiding van die woorde van Willi Marxsen (1976) steeds sê: Die Sache Jesu geht weiter!

\section{7. 'N LAASTE STELLING IN VERBAND MET DIE OORSPRONGE VAN DIE KANON EN DIE OORSPRONGE VAN DIE KERK}

Die ondersoek na die oorspronge van die kanon is soortgelyk aan die ondersoek na die oorspronge van die kerk. Kanonkritiek - op die spoor van Luther - kan nie los van kritiek (bedoelende solidêre kritiek) op die kerk gesien word nie. Dieselfde kriterium behoort in beide gevalle aangelè te word.

In die inleiding tot hierdie artikel het ek daarop gewys dat, net soos in die geval van die kanonvraagstuk (en wat Martin Luther reeds goed besef het), die moontlikheid groot is dat latere tradisies, maar ook bepaalde ontwikkelings in kerkbegrip, so kon afgewyk het van die Jesus-saak dat die grens van 'n akkommodeerbare verskeidenheid oorskry is.

Luther se voorwoord tot die Jakobusbrief ${ }^{4}$ is daarom na my oortuiging, ook in die geval van die kerkbegrip, ter sake:

Alle suiwer en heilige boeke ... stem daarin ooreen dat hulle almal saam Christus verkondig en geheel en al op Hom konsentreer (Christus predigten und treiben). Ook is dit die regte toetsteen waaraan ' $\mathrm{n}$ mens alle 
boeke kan (keur of) afkeur, as 'n mens sien of hulle geheel en al op Christus konsentreer (Christum treiben) of nie ... Wat nie Christuslering is nie, is nie apostolies nie, selfs al sou die heilige Petrus of Paulus dit leer. En omgekeerd, dit wat Christuslering is, is apostolies, selfs al sou Judas, Annas, Pilatus of Herodes dit bied.

(Luther [1522] 1967:177-178; vert deur A B du Toit 1984:280)

Die feit dat Luther sy Was Christum treibet-beginsel inhoudelik gevul het met Paulus se regverdiging deur die geloof, uit genade, moet ons nie van die kern van die Jesus-saak weglei nie. Ek is nie bewus van 'n meer kernagtige samevatting van die 'subversiewe wysheid' van die historiese Jesus as Romeine 1:17 nie! Strathmann (1970:41; vgl Gloege 1970:26; Du Toit 1984:280) is daarom geheel en al korrek deur te sê dat Luther in Romeine 1:17 die Kanon des Kanons herontdek het (kyk Maurer 1960:7071). In die inleiding tot die artikel het ek aangetoon dat die Reformasie op grond van ' $n$ historiese bewussyn ' $n$ afstand tussen die Bybel en die kerklike tradisie geskep het en dat Luther op 'n kritiese wyse in die Nuwe Testament tussen die fruhe Autorität en 'n abgeleitete Autorität onderskei het. Vanuit die perspektief van die Reformasie behoort die vraag na die kern van die Jesus-saak derhalwe op historiese, en nie op dogmatiese gronde nie, beslis te word 5 . Dit geld ook vir die vraag na die grense van aanvaarbaarheid wat die verskeidenheid in die kerk betref. Die vraag na die kriterium waarmee moontlike afwykings gemeet word, word met ander woorde nie bepaal deur enkelvoudig te vra of ' $n$ tradisie in die kanon of daarbuite voorkom nie. Dieselfde kriterium waaraan buite-kanonieke tradisies getoets word, behoort aangelê te word met betrekking tot binne-kanonieke tradisies. Die Jesus van die geskiedenis funksioneer, wat die kanonvraagstuk betref, as die kanon vóór die kanon (kyk Van Aarde 1994a:586-588; Marxsen 1976:45-62). Gloege (1970:25) wys daarop dat 'Luther (versteht) das in der Bibel sprechende Wort [ = Jesus Christus] als den Mutterschoß der Kirche' (my beklemtoning). Om as 'Christelik' tipeer te kan word, vereis, lyk dit vir my, 'n noodwendige historiese kontinuum met ten minste die kern van die Jesus-saak. 'n Soortgelyke moontlikheid van onaanvaarbare afwykings geld wat die ontwikkeling van die kerkbegrip en die voorkoms van verskillende ekklesiologiese voorstellings betref. Volgens Luther is daar in hierdie verband prinsipieel nie ' $n$ verskil tussen beskouings in die kanon en dié wat ná die vasstelling van die kanon ontstaan het nie - 'alle Lehre und Bücher - auch die des NT' (Maurer 1960:64 nota 24). In beide Skrif en tradisie funksioneer die Jesus van die geskiedenis as die maatstaf, die Prüfstein (Luther, in Strathmann 1970:42). So byvoorbeeeld sal 'n hiërargiese kerkorde, maar ook 'n nasionaal-partikuliere 'kerkbegrip' (soos dié van die Jerusalemse faksie onder lejding 
van Jakobus, die Ebioniete en die Nasareërsekte in Transjordanië) ewemin die toets slaag as die idee van 'n 'volkskerk' of 'n 'landskerk'/'nasionale kerk'. Dit geld enige tipe kerkbegrip waarvolgens die deelhê aan die eredienş-versamelde gemeente (institusioneel gesien of nie) bepaal word deur oortuigings wat afwyk van wat sedert Paulus met die inklusiewe $\dot{\varepsilon} \nu \mathrm{X} \rho \iota \tau \hat{\varphi}$-formule uitgedruk is. So byvoorbeeld sê Paulus in Galasiërs 3:28: 'Dit maak nie saak of iemand Jood of Griek, slaaf of vry, man of vrou is nie: in Christus Jesus is julle almal één' (Afrikaanse vertaling 1983). Die Pauliniese formule-agtige uitdrukking 'om in Christus' te wees, druk die grond van die bestaan van die kerk uit (kyk Van Aarde 1989:467; Neugebauer 1957:128-129). In 1 Korintiërs 12:12-13, 27 en Romeine 12:5 word dit deur Paulus voorgestel as 'n eenheid met die 'een liggaam in Christus' (kyk Bultmann [1958] 1968:311), en die outeur van Efesiërs (2:16) stel dit voor as 'n eenheid op grond van die kruisgebeure ( $\dot{\varepsilon} \nu \dot{\varepsilon} \nu \grave{\iota} \sigma \dot{\omega} \mu \alpha \tau \iota$ $\tau \hat{\varphi} \delta \iota \grave{\alpha} \tau o \hat{v} \sigma \tau \alpha \hat{v} \rho \circ \hat{v})$ (Van Aarde 1989:469). Die kruisgebeure as die 'gekondenseerde geskiedenis' van die lewe en werk van die historiese Jesus sedert sy geboorte verbind - ook wat die idee van sowel die kerk as die kanon betref - die Jesus van die geloof met die Jesus van die geskiedenis: 'Auch das Kanonverständnis Luthers ist ein Teil seiner Theologia crucis. Auch der Kanon bezeugt in seiner anfechtbaren Buchstäblichkeit die Niederigkeit, des ewigen Wortes das sich in die Menscheit verhüllte' (Maurer 1960:70-71).

\section{ENDNOTE}

1 Dat Luther se verstaan van die Skrif as krities en as histories bestempel kan word, blyk uit die volgende aanhaling van Gerhard Gloege (1970:23-24): 'Martin Luther setzt die Arbeit der Humanisten an den Schriften des Alten ... und des Neuen Testaments ... voraus. Unter Rückgriff auf den hebräischen und griechischen Urtext bedient er sich der philologisch-historischen Erkenntnisse der Zeit. In intensivem Studium der Bibel vernimmt er in neuer Weise Gottes eigene lebendige Stimme. Gottes Rede, die er in der Bibel zu hören beginnt, ist ihm aber nicht allgemeines "Wort Gottes", sondern das Evangelium Jesu Christi (solus Christus), das als Gnadenwort das Gerichtswort des Gesetzes überwindet (sola gratia) und im Glauben (sola fide) angeeignet wird: viva vox evangelii. Bei dieser Neuentdeckung werden alte Elemente der mittelalterlichen Überlieferung übernommen, aber sie erhalten vom Evangelium her neue Funktionen bzw. werden inhaltlich umgeschmolzen' (Latyn deur my beklemtoon).

2 'For Paul, the historical Jesus, particularly and precisely in the terrible and servile form of his execution, is part of Christian faith. It is to the historical Jesus so executed that he responds in faith' (Crossan 1994:10). 
3 'Dit wil sê: Dit is nie kinders wat in die gewone gang van die lewe gebore is, wat kinders van

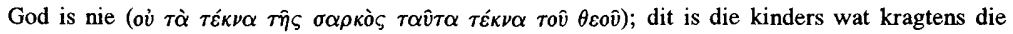
belofte van God gebore is, wat as Abraham se nageslag gereken word' (Rom 9:8).

4 'Darin stimmen alle rechtschaffenen heiligen Bücher überein, daß sie allesamt Christum predigen und treiben. Auch ist das der rechte Prüfstein, alle Bücher zu tadeln, wenn man sieht, ob sie Christum treiben oder nicht, sintemal alle Schhrift Christum zeigt, Röm 3,21, und St. Paulus nichts denn Christum wissen will, 1.Kor 2,2. Was Christum nicht lehrt, das ist noch nicht apostolisch, wenn's gleich St. Petrus oder Paulus lehrte. Wiederum, was Christum predigt, das wäre apostolisch, wenn's gleich Judas, Hannas, Pilatus und Herodes täte' (Luther, in Strathmann 1970:42).

5 Gerhard Gloege (1970:25) druk dit soos volg uit: 'Die Bibel ist für Luther in erster Linie nicht optisch, sondern akustisch verstehen. Mit diesem Bibelverständnis ist der theoretisch-doktrinäre Biblizismus erledigt. "Lehre" (doctrina) der Bibel ist ihm nicht Theorie, sondern die den Menschen und die Welt angreifende Verkündigung: Predigt. Jesus selbst schrieb kein Buch, forderte auch nicht die Jünger auf, Bücher zu schreiben, sondern hinzugehen und alle Völkern das Heil zu verkündigen: Die schriftliche Fixierung der Botschaft im Bibelbuch stellt nur einen Notbehelf dar, der durch das Abnehemen des Geistes in den ersten Gemeinden und das Auftreten der Irrlehre nötig wurde' (my beklemtoning).

\section{Literatuurverwysings}

Borg, M J [1994] 1995. Als met nieuwe ogen: De historische Jezus en waar het op aan komt in het geloof van vandaag, vertaal deur Peter Ros. Zoetermeer: Meinema.

Bousset, W [1913] 1926. Kyrios Christos: Geschichte des Christusglaubens von den Anfängen des Christentums bis Irenaeus. Göttingen: Vandenhoeck.

Bultmann, R [1958] 1968. Theologie des Neuen Testaments. 6.Aufl. Tübingen: Mohr.

- [1926] 1988. Jesus. Neuausgabe. Tübingen: Mohr (Paul Siebeck).

Christian, C W 1979. Fiedrich Schleiermacher. Waco, Texas: Word Books.

Cook, M L 1993. Responses to 101 questions about Jesus. New York: Paulist Press.

Conzelmann, H 1973. Jesus. The classic article from $R G G^{3}$ expanded and updated, translated by I \& F McLuskey with J M Robinson. San Francisco: Harper \& Row. 
Conzelmann, H 1988. History of early Christianity, in Conzelmann, H \& Lindemann, A, Interpreting the New Testament: An introduction to the principles and methods of N.T. exegesis, 336-335. Translated by S S Schatzmann from the 8th rev German edition. Peabody: Hendricksen.

Crossan, J D 1994. The historical Jesus in earliest Christianity, in Carlson, J \& Ludig, R A (eds), Jesus and faith: A conversation on the work of John Dominic Crossan, 1-21. Maryknoll, NY: Orbis Books.

Dunn, J D G 1991. The parting of the ways: Between Christianity and Judaism and their significance for the character of Christianity. London: SCM.

Du Toit, A B [1978] 1984. Kanoniek van die Nuwe Testament, in Roberts, J H \& Du Toit, A B, Handleiding by die Nuwe Testament, Band I, 81-294. Tweede verbeterde druk. Pretoria: NG Kerkboekhandel.

Gloege, G 1970. Zur Geschichte des Schriftverständnisses, in Käsemann 1970:1340.

Gnilka, J 1993. Jesus von Nazareth: Botschaft und Geschichte. Freiburg: Herder.

Horsley, R A 1989. Sociology and the Jesus movement. New York: Crossroad.

Kähler, M [1896] 1969. Der sogenannte historische .lesus und der geschichtliche, biblische Christus. 4.Auflage. München. (Theologische Bücherei. Neudrucke und Berichte aus dem 20.Jahrhundert, Band 2.)

Käsemann, E 1954. Das Problem des historischen Jesus. ZThK 51, 125-153.

- 1970. Das Neue Testament als Kanon: Dokumentation und kritische Analyse zur gegenwärtigen Diskussion. Göttingen: Vandenhoeck.

Kloppenborg, J S 1993. The Sayings Gospel Q: Recent opinion on the people behind the document. Currents in Research: Biblical Studies 1, 9-34.

Kümmel, W G 1970. Notwendigkeit und Grenze des neutestamentlichen Kanons, in Käsemann 1970:62-97.

- [1985] 1994. Vierzig Jahre Jesusforschung (1950-1990). Hrsg von H Merklein. 2.verbesserte und ergänzte Auflage. Bonn: Peter Hanstein Verlag. (Bonner Biblische Beiträge 60.)

Lüdemann, G [1994] 1994. The resurrection of Jesus: History, experience, theology, translated by J Bowden. Minneapolis: Fortress.

Luther, M [1522] [1963] 1990. Vorrede auf die Episteln S. Jacobi und Judae. WADB $7=$ Luther Deutsch. Die Werke Luthers in Auswahl, Bd.5.: Die Schriftauslegung. Hrsg von Kurt Aland. 4.Aufl. Göttingen: Vandenhoeck. (UTB 1656.) 
Malina, B J [1994]. Early christian groups: Using small group formation theory to explain Christian organizations. Unplubished paper, International Context Group Meeting, St Andrews University.

Marxsen, W 1970. Das Problem des neutestamentlichen Kanons, in Käsemann 1970:233-246.

- 1976. Jesus - Bringer oder Inhalt des Evangeliums?, in Die Sache Jesu geht weiter, 45-62. Gütersloh: Gütersloher Verlagshaus Gerd Mohn.

- 1992. Jesus and the church: The beginnings of Christianity, selected, translated, and introduced by P E Devenish. Philadelphia: Trinity Press.

Maurer, W 1960. Luthers Verständnis des neutestamentlichen Kanons, in Brown, H, Anderson W \& Maurer, H, Die Verbindlichkeit des Kanons, 47-77. Berlin: Lutherisches Verlagshaus. (Fuldaer Hefte 12.)

Neugebauer, F 1957. Das paulinische 'in Christo'. NTS 4, 124-138.

- 1961. In Christus/EN XPISTWI: Eine Untersuchung zum paulinische Glaubensverständnis. Göttingen: Vandenhoeck.

Neusner, J 1973. From politics to piety. Englewood, NJ: Prentice Hall.

- 1982. Formative Judaism: Religious, historical, and literary studies. Chico, CA: Scholars Press. (Brown Judaic Studies 37.)

- 1987. Israel: Judaism and its social metaphors. JAAR 55, 331-361.

Sanders, E P 1985. Jesus and Judaism. Philadelphia: Fortress.

Schille, G 1994. Die Jesusbewegung und die Entstehung der Kirche. ThLZ 119, 100-112.

Schillebeeckx, E 1974. Jezus: Het verhaal van een levende. Tweede vermeerderde druk. Bloemendaal: H Nielsen.

Schmithals, W 1994. Theologiegeschichte des Urchristentums: Eine problemgeschichtliche Darstellung. Stuttgart: Berlin.

Stanton, G N 1992. A Gospel for a New People: Studies in Matihew. Edinburgh: T \& T Clark.

Strathmann, H 1970. Die Krisis des Kanons der Kirche, in Käsemann 1970:41-61.

Strijdom, J M 1995. Diversiteit van die begin af: 'n Vergelyking van Mack en Crossan se konstruksies van die vroegste Christendomme (ca 30-70 n C). HTS 51/1, 108-133.

Trilling, W 1978. 'Implizite Ekklesiologie': Ein Vorschlag zum Thema 'Jesus und die Kirche', in Die Botschaft Jesu: Exegetische Orientierung, 57-72. Freiburg: Herder.

Tuckman, B W 1965. Developmental sequence in small groups. Psychological Bulletin 63, 384-399. 
Van Aarde, A G 1985. Skrifgebruik: Hermeneutiese riglyne. HTS 41, 547-578.

- 1987. Gedagtes oor die begin van die kerk - 'n geskiedenis van versoenende verskeidenheid. HTS 43, 325-351.

- 1989. 'n Nuwe-Testamentiese begronding van die eenheid van die kerk en die eis om kerkeenheid vandag. HTS 45, 461-475.

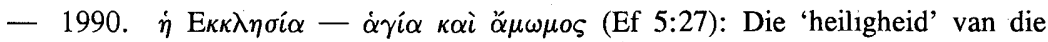
kerk teen die agtergrond van die breuk kerk-sinagoge. In die Skriflig 24, 251263.

- 1993. Aspekte van die sosiale stratifikasie van die ontwikkelde agrariese samelewing in die eerste-eeuse Palestina. HTS 49, 515-545.

- 1994a. The epistemic status of the New Testament and the emancipatory living of the historical Jesus in engaged hermeneutics. Neotestamentica 28/2, 575596.

- 1994b. The Evangelium Infantium, the abandonment of children, and the infancy narrative in Matthew 1 and 2 from a social scientific perspective, in Godwith-us: The dominant perspective in Matthew's story, and other essays, 261276. Pretoria: University of Pretoria. (HTS Suppl 5.)

- [1995]. The 'third quest' for the historical Jesus - where should it begin: With Jesus' relationship to the Baptizer, or with the nativity traditions? Neotestamentica 29/2. (Forthcoming.)

Vermes, G 1993. The religion of Jesus. Minneapolis: Fortress.

Westar Institute 1995. Jesus Seminar Votes, March 1995. Unpublished Report. Santa Rosa, CA.

White, L M 1988. Shifting sectarian boundaries in early Christianity. Bulletin of the John Rylands Library Manchester 70, 7-24. 